\title{
Knut Westlund
}

Professor Knut Westlund er død. Knut Westlund ble født 10.3.1923 og døde 27.2.2007 etter å ha vært syk i lengre tid.

Knut Westlund ble cand.med. fra Oslo i 1949 og fikk sin dr.grad fra Johns Hopkins University i 1953. Han var i perioden fram til 1972 tilknyttet Livsforsikringsselskapenes medisinsk-statistiske institutt på Ullevål sykehus. Fra 1972 til 1983 og senere fra 1989 til 1991 var han ansatt som professor ved Institutt for samfunnsmedisin (ISM), Universitetet i Tromsø. I perioden 1984-1989 var han forskningssjef ved Statens Helseundersøkelser i Oslo. Han har også arbeidet i India (for WHO) og som professor i Kuwait (1983-84). Knut Westlund fikk i 1991 tildelt St. Olavs orden for samfunnsgagnlig virke.

Da Knut Westlund ble ansatt som professor ved Universitetet i Tromsø i 1972, var dette som den aller første professor i epidemiologi i Norge. Hans betydning for norsk epidemiologi generelt og for forskningen ved Institutt for samfunnsmedisin spesielt tror vi vanskelig kan overvurderes. Hans interesser var særlig innen de kroniske sykdommers epidemiologi, med vekt på de kardiovaskulære sykdommer og diabetes der han har gitt store bidrag. Selv om han behersket kompliserte metoder innen faget, var han særlig de store, grundige, tabellers mann. Han ønsket å vise sine funn på en så enkel måte at man ikke trengte å bruke kompliserte, statistiske metoder med mange forutsetninger.

Hans beskjedenhet var legendarisk og han satte ikke sitt navn på mange publikasjoner. Ofte må man lete grundig for å oppdage hans bidrag. Han bidro desto mer til mange andres faglige utvikling ved sin veiledning og rådgiving. Fremdeles, mer enn 15 år etter at han gikk av med pensjon, kan man høre referanser til Knut Westlund på ISM. Her, som i andre deler av norsk epidemiologi, har han sine faglige "barn", "barnebarn" og endatil "oldebarn"! Vi står i stor gjeld til han.

Westlunds krav til faglighet var absolutt og han kunne være direkte og skarp i sin kritikk av utviklinger i faget som han ikke syntes noe om. Hans ironi kunne virke farlig presis. Men som menneske var han blant de mest elskelige og med omsorg for personene rundt seg.

Westlund fortalte engang en historie (gjengitt i Norsk Epidemiologi 1991; 1: 3-7) om en mann som hadde vært professor ved Universitetet i Tromsø, og derfor slapp inn i himmelen fordi St. Peter syntes synd på han. Da det etterpå kom en mann som to ganger hadde vært professor ved Universitetet $\mathrm{i}$ Tromsø (som Westlund jo hadde), ble han avvist. Fordi himmelen skulle jo ikke være en idiotanstalt. Nå er Westlund $\mathrm{d} \varnothing \mathrm{d}, \mathrm{og}$ vi håper at St. Peter likevel så i nåde til denne store inspirator for norske epidemiologer slik at også St. Peter kan få høre Shakespeares sonater sitert; etter hukommelsen!

\section{Kollegaer ved Institutt for samfunnsmedisin, Universitetet $i$ Tromso}

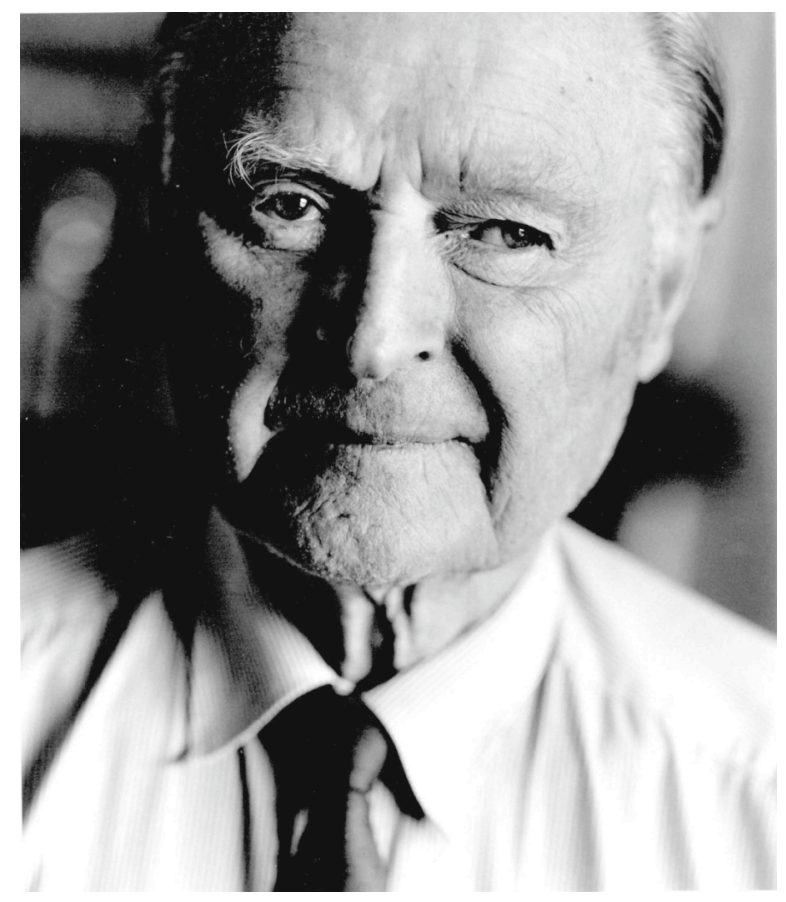

